\title{
EXCEPTIONS TO THE LIABILITY OF TRUSTEES
}

\section{David B. Zoobt}

Limitations upon the trustee's liability for breach of trust present an interesting problem thrust into the foreground by the turbulent economic situation of recent years. As always, the human desire to speculate has caused beneficiaries as well as trustees to succumb to the Crœsus complex engendered by prosperity; consequently, the trust questions most frequently litigated or in process of adjustment generally involve attempts to surcharge trustees with losses predicated either on investment in non-legal securities or on unauthorized retention of non-legal investments acquired from the estate of the testator or settlor. ${ }^{1}$ In situations where the beneficiaries under the trust have acquiesced or concurred in or released the wrongful acts complained of, the trustee may seek sanctuary under the enveloping folds of a doctrine based on the trinity of "Consent, Affirmation and Release", commonly referred to as "exceptions" to the liability of a trustee for breach of trust. $^{2}$ The extent and implications of these exceptions are not confined to speculative investments of the character mentioned above; they reach as well a breach of any of the other duties owed by the trustee to the cestui que trust, some of which grow out of the relation itself, others of which are dictated either by the terms of the trust or by statute. ${ }^{3}$

Moreover, such exceptions have been accepted from an early date without comment or analysis as an inherent and even desirable principle of law

$\dagger$ A. B., I923, LL. B., I927, LL. M., 1934, University of Pennsylvania; member of the Philadelphia Bar.

I. The making of unauthorized investments and the retention of non-legal securities received from the estate of testator have always been pressing problems during speculative times and "few things are more common than for the beneficiary to concur in and evensuch is the desire of poor mortals for an increase of their income-to instigate breaches of trust". BrRRELI, The Duties AND LIABIIITIES of TRUSTEES (I897) II6. For discussion of the problem of continuation of a decedent's business by his trustees or personal representatives see Note (IgII) 40 A. L. R. (N. s.) 234 See also Note (I873) 44 L. R. A. (N. S.) 896, 95I.

2. The rule has been generally stated as follows: "If trustees make an improper investment with the knowledge, consent and acquiescence, or at the request of the cestui que trust they cannot be held to make good the loss, if one happens; but the cestivi que trust, to be affected by such consent or acquiescence must be sui juris." PERRY, TRUSTs and TRUSTERs (7th ed. I928) \$ 467. See also Hill, The Law Retating to Trustees (4th Am. ed. I867) 82I: "A trustee may be exonerated from the consequences of a breach of trust, either by an express release from the cestui que trusts, or by their having concurred or acquiesced in its commission."

3. Among such duties are: (I) duty to administer the trust, (2) duty of loyalty, (3) duty not to delegate, (4) duty to keep and render accounts, (5) duty to furnish information, (6) duty to exercise reasonable care and skill, (7) duty to take and keep control, (8) duty to preserve the trust property, (9) duty to enforce claims, (IO) duty to defend actions, (II) duty to keep trust property separate, (12) duty with respect to bank deposits, (13) duty to make the trust property productive, (I4) duty to pay income to beneficiary, (I5) duty to deal impartially with beneficiaries, (I6) duty with respect to co-trustees. See Restatement, TRUSTS (Tent. Draft, I930) §§ I64-I79. 
by all writers on trusts. ${ }^{4}$ As long ago as the beginning of the nineteenth century, the doctrine had assumed such proportions that it was conventionally accepted by the practitioners of the time as an unquestioned method of protecting trustees. In a series of lectures delivered before Lincoln's Inn in the year $1825,{ }^{5}$ the exceptions were alluded to as a protection against the uncertain liability which confronted the trustee in the performance of his duty. The gratuitous nature of the trust office, the difficulties of obtaining competent advice, the delay and expense of obtaining a decree of the court of chancery to guide the trustee-all tended toward making the doctrine of the exceptions socially desirable. ${ }^{6}$ Yet, in view of the somewhat summary manner in which the doctrine of the exceptions is today being applied, it would seem pertinent to re-examine the historical and logical premises of the rule for the purpose of determining its validity and desirability under present conditions.

The task is too broad to permit a treatment of all the questions impinging upon the main inquiry: the extent of the right of beneficiaries who have not assented to the breach of trust to contribution from the assenting beneficiary's interest in the trust; ${ }^{7}$ the doctrine of laches as a bar to the beneficiary's recovery $;^{8}$ the extent to which deviation and even termination of trust can be permitted with the consent of the beneficiary. ${ }^{\circ}$ These and a number of other important problems are necessarily incidental. They can be touched upon only in passing, since their inclusion would not materially aid in an analysis of the raison d'être for the exceptions.

The trust device now accepted as an ordinary mechanical incident in the disposition of property did not have legal existence until a method of enforcement became available. ${ }^{10}$ As Lewin puts it:

"Originally the only pledge for the due execution of the trust was the faith and integrity of the trustee; but the mere feeling of honour

4. See Spence, Equitable Jurisdiction of the Court of Chancery (1849) 936, 937 ; Hini, The Law Relating to Trustees (4th Am. ed. I867) 82I; 2 Beach, Law of Trusts AND TRUSTEES (1897) \&695; UNDERHIII, TRUSTS AND TrUSTEES (Ist Am. ed. 1896) 468 ; LoRing, Trustees HaNdBooK (3d ed. I907) I76 et seq; Godefror, Trusts and Trustees (5th ed. I927) 694; LEwIN, TRUSTS (I3th ed. I928) 974 et seq.; 28 HaLSBURY, Laws of ENGLAND (I914) \& 399, et seq.

5. Sir George Francis Hampson, A Short Treatise Endeavouring to Point Out the Means by Which Those Who Accept the Situation of Trustees May Perform Their DUTIES WITHOUT INCURRING RESPONSIBIIITY (I825).

6. Ibid.

7. See GoDEFroI, op. cit. supra note 4 , at 684 .

8. See Restatement, Trusts (Tent. Draft, I932) \$2II. In England by statute the trustee is entitled to plead the Statute of Limitations, except where the claim is founded upon fraud or is to recover trust property the proceeds of which are still retained by the trustee. 28 HALSBURY, LAwS OF ENGLAND (1914) \$ 402 .

9. For a discussion of the extent to which deviation is permissable, see Scott, Deviation from the Terms of a Trust (193I) 44 HARv. L. Rev. 1025.

10. See I Parker, Chancery (I807) 20; 4 Holdsworth, History of the English LAw (I924) 4 II et seq. 
proving, as was likely, when opposed to self-interest, an extremely precarious security, John Waltham, Bishop of Salisbury, who was Lord Keeper in the reign of Richard the Second, originated the writ of subpona, by which the trustee was liable to be summoned into Chancery, and compellable to answer upon oath the allegations of his cestui que trust. No sooner was this protection extended, than half the lands in the kingdom became vested in feoffees to uses, as trusts were then called. Thus, in the words of an old counsellor, the parents of the trust were Fraud and Fear, and a Court of Conscience was the Nurse." 11

There were thus created between the trustee and the beneficiary personal relationships with which the Chancery courts were called upon to deal. As will be demonstrated later, the rights of the settlor to compel enforcement were given little or no regard. It could naturally be expected that the Chancery courts, separated as they were from the law courts, would incline to be less rigid in their treatment of the interests involved and that the pleas of trustees based upon appeals to the conscience would under certain circumstances not fall upon deaf ears. ${ }^{12}$ The correctness of this conclusion and the nature of those circumstances are adequately demonstrated by the earlier cases upon the subject.

It was Lord Cowper who laid the groundwork upon which the rule of the exceptions was later to be based by allowing as a major consideration the balancing of personal equities rather than the creation of any hard and fast rule of law designed to preserve and protect the trust device. In Fellows $v$. Mitchell \& Owen ${ }^{13}$ two trustees of a mortgage had joined in an assignment of the same, and each had receipted for the whole although they had received only a moiety. Upon one trustee's becoming insolvent, the beneficiary attempted to charge the remaining trustee for the whole amount. In denying liability for more than the amount actually received the Court stated:

"It is attended with circumstances, somewhat uncommon; for the cestui que trust has admitted, that he was present and consenting to the payment of the money in moieties, and that at his importunity the trustees joined in an acquittance for the whole. . . The equity in this case is so obvious that it will weigh with me (if there are no direct precedents to the contrary) against any arbitrary rule laid down in any age." 11

That a balancing of personal equities was the moving consideration in arriving at a judicial determination was again admirably demonstrated in Smith and Helen his Wife $v$. French. ${ }^{15}$ A mother on the wedding day of her daughter, Helen, made herself trustee of 1000 pounds invested in certain

II. LEWIN, op. cit. supra note 4 , at I.

I2. See 4 HoldsworTH, op. cit. supra note Io, at $418,432$.

I3. I P. Wms. 8I (Ch. i705).

I4. Id. at 81,83 .

I5. 2 Atk. 243 (Ch. I74I). 
certificates for the sole and separate use of her daughter, with certain remainders over. The husband of the daughter, being sorely pressed by creditors, prevailed upon the mother to loan him the certificates to be exchanged for other securities at a profit but instead of so doing, he misappropriated them for his own use. Upon the threats and requests of the mother 350 pounds were returned, but the husband died insolvent, and the balance was lost. The daughter then married one Smith, and together they brought proceedings to surcharge the mother for breach of trust. The mother answered that at the importunities of her daughter and deceased son-in-law she had loaned the latter the certificates and that he had used them improperly; that she had threatened to sue but had yielded only on the importunities of her daughter made on bended knee, who time and time again, both before and after the death of her husband, had agreed to release any demands that might be made against her mother. During the course of the argument the Chancellor was reported as follows:

"The principal question here is, Whether upon all the circumstances of this case, the defendant has been guilty of a breach of a trust, and this must depend upon the defense which she has set up by way of rebutter to the plaintiff's demand; if it stood clear of such circumstances there could not be a plainer breach of trust than delivering these tallies to the husband.

"But the present case appears to me to be a very hard and a very harsh demand in a court of equity, as it is circumstanced, taking the evidence on both sides to be true. . . .

"In the first place: here is a very strong equity for the mother, that what she did in this affair was at the importunity and repeated solicitations of the daughter, and who since the death of her first husband has over and over again offered to execute a release, when she might beyond all contradiction have done it; for though the assignment was an unfortunate transaction for the daughter, yet as it was done at her own request, she could not blame her mother for it.

"And as it is an extreme harsh one after all the kindness and tenderness the plaintiff Helen has received at her mother's hands I am of opinion that the defense is very sufficient to rebut all the plaintiff's equity." 16

Although the Lord Chancellor characterized the beneficiary's conduct as a mere request, the case reveals that there was also an inducement based on a family relationship. It involved a request which could not morally have been denied, and the equities of the situation led Lord Hardwicke to treat the petition for surcharge as a harsh demand. Furthermore, the language of the opinion seems to raise a doubt as to whether under all the circumstances of the case the defendant had actually been guilty of a breach of trust. Of course, if circumstances absolve the trustee from a breach of trust, there is 
no occasion for applying any doctrine of estoppel. This intimation of Lord Hardwicke has never been confirmed. In the application of the exceptions the trustee's acts have been $a$ priori assumed to be a violation of his trust. It is the remedy which is denied.

The principle so doubtfully recognized by Lord Hardwicke in Smith and Helen soon became the accepted doctrine, but it was not long limited to situations where the trustee's breach was premised upon "inducement", for three years later in Trafford v. Boehm ${ }^{17}$ we find Lord Hardwicke using as the rationale of his decision, the term, "approbation", which covers a situation factually far removed in scope and effect from the limits of the previous decision. In that case, a trust with husband and wife as beneficiaries was created, the monies of which were to be invested in lands for the benefit of the marriage settlement. Pending the acquisition of suitable lands, the trustee was directed to invest in government funds or other good security as the husband cestui que trust might direct. The trustee, at the husband's direction, invested in South Sea stock, and several thousand pounds were lost. Upon the death of the husband, the wife brought a bill to obtain the benefits intended under her marriage settlement. The trustee filed a cross bill, praying among other things to be discharged from all liability in connection with the investment in the South Sea stock. Lord Hardwicke held that the investment, not being a good security as required under the trust, was clearly in breach of trust, and that the loss should be made good out of the share of plaintiff's husband, the fellow beneficiary under the trust. It was stated:

"The rule of the court in all cases is, that if a trustee errs in the management of the trust, and is guilty of a breach, yet if he goes out of the trust with the approbation of the cestui que trust, it must be made good first out of the estate of the person who consented to it." 18

In using the term "approbation", the court may have intended a larger significance than might have been conveyed by the terms "direction" or "consent", for stress is laid upon the fact that thereafter the cestui que trust had approved the various accounts showing this loss and had constantly received dividends. Any doubts as to the scope of the decision may be considered as effectively removed by the broad and unqualified language of Lord Eldon in Brice $v$. Stokes, ${ }^{19}$ where one trustee with the knowledge of the cestui que trust permitted his co-trustee to use trust monies for the latter's personal benefit. Lord Eldon said:

"It is clear, upon the settled cases, that if there are two trustees, and a transaction takes place, in which the fund is taken out of the state, in which it ought to have remained, and is not placed in the state in which

17. 3 Atk. 440 (Ch. 1746).

I8. Id. at 444 .

Ig. II Ves. 319 (Ch. I805). 
it ought to be, but is kept in hands, that ought not to retain it, if any particular Cestui Que Trust has acted in authorizing that as much as the trustee, who has not the money in his hands and continues to permit it to be so treated, in a question between the Cestui Que Trust and that trustee the latter cannot be called upon by the former." 20

From these advances in Trafford v. Boehm and Brice v. Stokes, it was but a short step to extend the principle to cases in which the acquiescence or affirmance was subsequent to the original act or was in the nature of a release. In Walker $v$. Symonds, ${ }^{21}$ the trustees failed to invest in mortgages or government securities as required under the trust and loaned the funds to one of the heirs and co-trustees without security. A release was later obtained from the cestui que trust, a young woman, who though of age was unversed in the management of financial affairs. The funds having been lost, the cestui que trust brought action. Lord Eldon, in surcharging the trustee and denying the validity of the release as a defense, said:

"It is established by all the cases, that if the cestui que trust joins with the trustees in that which is a breach of trust, knowing the circumstances, such a cestivi que trust can never complain of such a breach of trust. I go further, and agree that either concurrence in the act, or acquiescence without original concurrence, will release the trustees: but that is only a general rule, and the Court must inquire into the circumstances which induced concurrence or acquiescence; recollecting in the conduct of that inquiry, how important it is on the one hand, to secure the property of the cestui que trust; and on the other, not to deter men from undertaking trusts, from the performance of which they seldom obtain either satisfaction or gratitude." 22

The problem before the court does not seem to have been fully argued in prior decisions, and the result is to be explained only by the nature of the factual situation involved. The fundamental policies of equity in dealing with fiduciary relationships are manifested in the restrictions placed on the power of beneficiaries to exonerate their trustees. There must be full disclosure on the part of the trustee and competency on the part of the beneficiary. ${ }^{23}$ Thus the absence of the latter requisite in the case under discussion operated to surcharge the trustee, notwithstanding the beneficiary's acquiescence.

The finality of Lord Eldon's language admits of no exception-the cestui "can never complain." This was unjustified, in view of Ryder v. Bick-

20. Id. at 325-326.

21. 3 Swans. 1, 64 (Ch. I8I8).

22. Id. at 64 .

23. The incompetency which was before Lord Eldon was neither one of age nor of limitation imposed under the trust instrument, but rather one arising from the inability of the cestui que trust to comprehend and understand not only the nature of the wrongful act but also the effect of the release. The principles applicable together with an extensive citation of authority are given in RESTATEarent, TRUSTS (Tent. Draft, 1932) §208. Identical principles are applied to discharge of liabilities by release and by subsequent affirmance. Id. $\$ \$ 209,210$. 
erton. $^{24}$ In that early case it was established by Lord Hardwicke that the beneficiary's acquiescence or consent might, by virtue of the terms or purposes of the trust instrument, be ineffective to discharge the trustee of liability. A trustee of a wife's separate use trust had, with the wife's consent, placed 800 pounds with the trustee's uncle, without taking the security required by the terms of the trust. The Chancellor stated:

"The power of the wife must arise out of the articles for after the marriage she had no power to prejudice herself. The power is that she and her husband must consent to the placing out of the money on security. Therefore, she could not consent to the placing out of the money on no security at all."

There were thus presented conflicting desires: on the one hand to weigh the personal equities existing between the parties, and on the other to preserve the terms and purpose of the trust as dictated by the settlor. While the decision seems to rest upon the narrow ground that the investment itself was a violation of the testator's will in that regard, it is quite apparent that the purpose of the trust was to afford protection to one whom the testator deemed incapable of managing her own affairs, a married woman, and that this consideration was regarded as paramount.

In England, the problem of how far married women under separate use trusts were capable of releasing or acquiescing was one on which the courts could arrive at no complete accord. ${ }^{25}$ The final solution is still a matter of discretion to be based upon the personal equities involved.

Before the passage of the English Trustee's Act of $1888,{ }^{26}$ a trustee was afforded little protection under the exceptions when property was settled upon a married woman in a simple trust or settled to her separate use with restraint upon anticipation or alienation. By the terms of that Act however it was provided:

"Where a trustee commits a breach of trust at the instigation or request or with the consent in writing of a beneficiary the High Court may if it thinks fit and notwithstanding that the beneficiary may be a married woman entitled for her separate use and restrained from anticipation make such order as to the court seems just for impounding all or any part of the interest of the beneficiary in the trust estate by way of indemnity to the trustee or person claiming through him."

The Act did not operate to curtail or affect the previously existing rights and remedies of trustees. It altered the law in no respect other than to enlarge the power of Chancery to indemnify trustees, especially where married

24. 3 Swans. 90 (Ch. 1743).

25. See Goderroi, Trusts and Trustees (I927) 687, 688.

26. 5 I \& 52 VICT. c. $59, \S 6$ ( 1888 ). This section was reenacted in $52 \& 53$ VIcT. c. $32, \S 45$ (1893) and in 15 GEo. V, c. 19, \$62 (1925). 
women without power of anticipation were involved. ${ }^{27}$ While not permitting the trustee to avail himself of instigation and consent as an absolute defense against primary liability, the Act is significant in that through its passage the doctrine of the exceptions at last received concrete, statutory recognition.

The conditioning social and economic factors underlying the growth up to this point of the doctrine of consent, concurrence and release are implicit in the cases already discussed. In the early cases developing the doctrine there was a relationship of blood or affection between the parties involved. ${ }^{28}$ While it may be argued that little significance attaches to this fact in and of itself, it must be remembered that under the system of equity as administered by the Chancery court ethical and moral considerations would be given great weight in balancing the personal equities between the cestui que trust and the trustees. It could psychologically be expected that trustees would more easily be influenced by importunities or requests made by those enjoying relationships of blood or affection. To deny relief under such circumstances would have permitted cestuis que trustent to traffic in normal human emotions. It was the reaction to this circumstance which was so strongly revealed in Lord Hardwicke's opinion in Smith and Helen. Had the rule been confined to this early basis, little fault could be found with it.

As a correlative factor, there was a complete absence of corporate trustees. The trust was accepted not as a matter of profit, but as a gratuitous burden. Nothing was better established in England at the time the exceptions were first developed than that a trustee could have no allowance for his time and trouble. Even today in England compensation is permitted only where it is directed by the testator's will or, in exceptional circumstances, by the court. ${ }^{29}$ Accordingly, aside from the sentimental considerations favoring one who accepts an unremunerative task for the sake of benefiting others, it becomes important, in Lord Eldon's language, "not to deter men from undertaking trusts for the performance of which they seldom obtain either satisfaction or gratitude." 30

The natural tendency to minimize and excuse breaches of trust where a gratuitous trustee has acted honestly later received further expression in

27. Even under the Act, when consent in writing had been obtained, it was still necessary to show that the beneficiary had acted with full knowledge of the facts which made the act complained of a breach of trust. In re Somerset [I894] I Ch. 23I. See also Godefror, op. cit. supra note 4 , at 684 ; LEwIN, op. cit. supra note 4 , at 960 .

28. Cf. Smith and Helen his Wife v. French, 2 Atk. 243 (Ch. 174I), cited note 15, supra (mother and daughter); Walker v. Symonds, 3 Swans. I, 59 (Ch. I8I8) (relatives and close family friends), cited note 2I, supra; Booth v. Booth, I Beav. I24I (Ch. I838) (trustee a brother and partner of testator, and trustee's wife a beneficiary) ; Broadhurst v. Bolguay, I Y. \& C. C. I6 (Ch. I84I) (brothers-in-law); Farrant v. Blanchford, I De G. J. \& S. 107 (Ch. 1863) (trustee father of one of beneficaries).

29. 2 Spence, Equitable JuRisdiction of the Court of Chancery (I849) 937; 2 Perry, Trusts and Trusters ( 7 th ed. I929) \$904.

30. Walker v. Symonds, 3 Swans. I, 64, cited notes 2I, 22, supra. 
England in the Debtors Act of 1878 , in which the courts were given discretion as to whether or not execution should issue against a trustee found guilty of negligence but not of dishonesty. ${ }^{31}$ And under the Judicial Trustees Act of $1893^{32}$ and the Trustee Act of $1925,{ }^{33}$ trustees who had acted honestly and reasonably might be excused wholly or in part from personal liability for breach of trust.

The imposition of different degrees of liability according as the undertaking is gratuitous or for gain is common in other fields of law. For one illustration, a gratuitous bailee has always been held to a lesser duty of care towards his bailor than a bailee who is working for hire. ${ }^{34}$ While statements have been made that no such refinement exists in the law of trusts, ${ }^{35}$ there is no doubt that the trustee's lack of compensation was a strong motivating factor in developing the rule of exceptions. If trustees had been paid, the judges would have been less fearful of discouraging men from assuming trust responsibilities. The absence of remuneration meant also that there existed no class of professional trustees. The trustee was almost invariably a novice in that relationship, unacquainted with its legal intricacies and not infrequently inexperienced with the problems of its management. The historic background is well portrayed by an early text-writer, who has given a vivid picture of the difficulties besetting those who from a spirit of friendliness or loyalty were induced to accept the position of trustees, only to find that their inexperience has exposed them to a petition to surcharge. ${ }^{38}$

3I. 4 I \& 42 VICT. c. 54 (I878), amending the Act of I869. In Earl of Aylesford v. Earl Poulett [1892] $2 \mathrm{Ch}$. 60 , the defaulting trustee had not been guilty of dishonesty, and the monies appeared to have been applied on behalf of the cestui que trust under a mistaken view in payment of debts of a class which were not within the terms of the trust. The court exercised its discretion and refused to permit any attachment to issue. See also In re Smith [1893] $2 \mathrm{Ch}$. I, where the court exercised a similar discretion and refused to permit execution against the trustee guilty merely of negligence in trusting too much a dishonest trustee.

32. 56 \& 57 VICT. c. 53 (I893).

33. I5 Geo. V, c. I9, §6I (I925) : "If it appears to the court that a trustee, whether appointed by the court or otherwise, is or may be personally liable for any breach of trust, whether the transaction alleged to be a breach of trust occurred before or after the commencement of this Act, but has acted honestly and reasonably, and ought fairly to be excused for the breach of trust and for omitting the directions of the court in the matter in which he committed such breach, then the court may relieve him either wholly or partly from personal liability for the same."

Mr. Augustine Birrell (op. cit. supra note I), after calling attention to the earlier strictness of courts of equity in applying to trustees a high standard of care and skill, points out the effect of the change in procedure permitting oral testimony. He says (at I6):

"Now it is all different. The real Trustee, for example, goes into the box-some farmer, it may be, who from a sense of cronyship has consented to act as a Trustee under the will of a neighbor with whom on market days he has often had a friendly glass. There he stands, ignorant for certain, pigheaded very likely, quarrelsome possibly, but honest, palpably honest and perspiring. He is charged with losses occasioned by his disregard of the strict language of a will he never understood, or for not having properly controlled the actions of his cotrustee, the principal attorney of his market town.

"It may be necessary to ruin such a man, to sell his horses and his cows, his gig and his carts, and to drive him from his old home, but it cannot be done without a qualm. Hence has come about that new spirit and temper to which I have ventured to refer at too great length."

34. See 3 COOLEY, TORTS $\$ 457$ (4th ed. I932).

35. Wood, The Myth of the Gratuitous Trustee (I898) Io JuRI. REv. 152.

36. HAMPSON, op. cit. supra note 5, at 5-II. See BIRREI, oph cit. supra note I, at I6. 
Today, however, when the bulk of trust estates are administered by corporate trustees, in business for profit and representing themselves as specially qualified, it is doubtful if the protection afforded the trustees under the plea of good faith and exceptions to liability is any longer socially desirable. The distinction has been felt by the English Court of Appeals, which has intimated that a corporate trustee, paid for its services and in business for the very purpose of administering trust estates, might not be entitled to the remedial provisions of the Trustees Act referred to above. ${ }^{37}$ On the whole, in view of the development of the corporate trustee, the almost complete disappearance of the wife's separate use trust, and the disintegration of family ties as a means for perpetuating lineage and wealth, it is an open question whether the sentiments of the early English chancellors are entitled to an abiding force. ${ }^{38}$

\section{II}

Relatively nothing has been added to the doctrine of the exceptions by the American cases. It was transplanted and accepted almost in toto by the American courts. Indeed, the same social conditions which were conducive to liberalism in dealing with the liability of a trustee were present in America, and the courts did not find it necessary to re-examine the historical or logical premises of the rule. As to the rule itself, nothing has been added by the later decided English or American cases, except the verbiage designed to express its mechanism. Under a given set of facts involving affirmation, consent or release, the result is nearly a foregone conclusion.

"Estoppel" is the word frequently called upon by the courts to rationalize their position. Yet none of the existing theories of that convenient

37. Cf. National Trustees Co. of Australasia v. General Finance Company of Australasia, [1905] A. C. 373,381 .

38. In Re Clark's Will, 136 Misc. 881, 889, 242 N. Y. Supp. 210, 220 (Sur. Ct. I930) the court pointed out that the fact that the trustee was a trust company was an important if not decisive factor in the imposition of liability.

"In trust relations these days, when trust companies have entered the business, much more is expected from a corporate trustee than from the old fashioned individual executor or trustee. Trustees seek this character of business, claiming that they are specially qualified and financially responsible. They make a specialty of trust matters and claim to be familiar with the authority of executors and trustees as to trust investments. They have claimed that each estate and trust will receive the personal attention of one trust executive whose life work is the administration of estates and trusts, and decisions with regard to the purchase and sale of securities will be independently arrived at by these officers in consultation with investment experts. The courts, and particularly the Surrogate's Court, vigilantly enforce the highest standard of fidelity of trustees and zealously guard the rights of beneficiaries."

While the Clark case was overruled by the Court of Appeals in 257 N. Y. 132, 177 N. E. 397 (I93I), no reference is made in the upper court's decision to the distinction suggested by the lower court.

In Linnard's Estate, $299 \mathrm{~Pa} .32,39,148$ Atl. 912, 914 ( 1930 ), it was argued that "a stricter rule of responsibility should be exacted from trust companies as fiduciaries than from the ordinary individual trustee", but the court said that the record in the case did not "warrant consideration of any such advance in the law", and that "rulings which involve enlarged application of established principles to new conditions, and, when subsequently followed, give rise to what become known as new or advanced principles, should be made only in cases where the facts relied on plainly appear and clearly call for such rulings". 
device are correctly applicable. A case for the orthodox estoppel in pais can be made only in disregard of one of its fundamental elements. Since the trustee is not deceived into believing that his act is not in fact a breach of trust, but is well aware of the risks and liabilities ordinarily involved, it is clear that he cannot show a misrepresentation of an existing state of facts. The doctrine of promissory estoppel, as described by Professor Williston, ${ }^{39}$ is likewise unavailable, because of the absence, in the ordinary case, of any promise by the beneficiary that he will not hold the trustee liable for the breach. Under either theory, also, if estoppel by inducement is a basis of the principle, then consent, affirmation or release given by the beneficiary after the breach of trust has resulted should not prevent surcharge for losses incurred before the beneficiary has acted. Apparently, however, no case has ever distinguished those situations where the beneficiary's consent was given prior to the improper conduct from those where the consent was subsequently obtained. If "estoppel" applies in the latter instances, it does so with a skillful retroactiveness. Furthermore, no case seems to involve any inquiry or comment by the court as to whether or not there was any testimony presented indicating that the trustee would have abandoned his wrongful position had the beneficiary so desired. ${ }^{40}$ The trustee having first deviated from the terms of a trust, the courts all seem to have assumed that the subsequently obtained consent or affirmation of the beneficiary was the decisive factor in persuading the trustee to continue his improper conduct. The inference is that if the beneficiary had not given his consent or affirmation to the deviation, the trustee would promptly have ceased his deviation and once more conducted himself as he should. It is contrary to human experience to assume that the trustee, having voluntarily entered upon a wrongful course of conduct, would invariably have abandoned that position if he had not received the consent, acquiescence or assent of the cestui que trust. From this point of view, therefore, it is submitted that mere proof of the beneficiary's acquiescence plus the additional safeguards covering the beneficiary's knowledge of the facts, the law, and his relationship with the trustee, should not be enough to induce the courts to apply a doctrine of estoppel without evidence of the trustee's willingness to act in accord with the beneficiary's disapproval of the trustee's deviation.

In a situation where liability on the part of the trustee is denied because of a release, formal or otherwise, the courts do not expressly apply the doctrine of estoppel, but deal with the more formal concepts of a contractual

39. I Williston, Contracts (I920) 307 .

40. A trustee who deviates from the terms of a trust with the beneficiary's consent is liable for a continuation of the deviation after the beneficiary has retracted his consent. Sherman v. Parish, 53 N. Y. 483 (I873) (improper investment); Restateinent, TRUSTS (Tent. Draft, 1932) $\$ 208$. 
relinquishment and abandonment of a right. ${ }^{41}$ The validity of the release, however, is not tested solely by the ordinary concepts of contract law. It is required in addition that the cestui que trust be competent and under no disability, and that there be full disclosure and fairness.

This doctrine of release raises an interesting analogy to that principle of trust law which permits the beneficiary under certain conditions to void contracts made with his trustee in reference to the trust property. Where the trustee has failed to reveal that the trust property is involved, the contract is voidable by the beneficiary with no further showing. However, where the beneficiary is advised that the trustee is dealing with the trust property and consents thereto, the contract is voidable only if in the judgment of the court there has not been full disclosure and fairness. ${ }^{42}$ It follows that where the trustee has committed a breach of trust by dealing with trust property for his own benefit without the knowledge of the beneficiary, and has subsequently obtained a release, the only inquiry of the court is directed toward the validity of the release. That is, the issue is no longer the character of the trustee's violation, but rather the nature of the conditions under which the release was given and obtained.

The question of consideration for such a release is one with which the courts seem little concerned: Where the release is given before any damage has resulted to the beneficiary, no great difficulty is presented, as the courts may then revert to their theory of estoppel. However, where the loss has been irrevocably established before acquiescence by the beneficiary, a release by the cestui que trust which is not supported by adequate consideration must necessarily partake of the quality of a gift. The situation has been considered to require the sanctity of a formal release. ${ }^{43}$ But since it is well established that in equity a seal has no binding effect, this reasoning would seem to be inaccurate. In several of the early Chancery cases, while the question of consideration seems to have been discussed, there is no definite statement as to its necessity, and the court places emphasis only upon the elements of fairness and full disclosure.

In all these cases the courts paid little or no attention to the trustee's various duties, inherent in the trust relationship. Amongst these is that of loyalty; a duty whose breach is completely condoned under the governing principles

4I. See Pope v. Farnsworth, 146 Mass. 339, 344, I6 N. E. 262, 266 (1888) ; cf. French v. Hobson, 9 Ves. 103 (Ch. 1803); Wilkinson v. Parry, 4 Russ. 272 (Ch. I828); Aylwin v. Bray, cited in Small v. Attwood, 2 Y. \& J. 512, 517 (Ex. I828); Blackwood v. Borrowes, 2 Con. \& Law (Ir. Ch. 1843). But see Thomson v. Eastwood, 2 App. Cas. 215, 234, 247 (I877). 42. Restatemrent, Trusts, Explanatory Notes (I93I) $\$ 165$. The cases are numerous to the effect that a sale of trust property by the trustee to himself individually is voidable by the beneficiary. Broder v. Conklin, 121 Cal. 282, 53 Pac. 699 (1898) ; Bennett v. Weber, 323 IIl. 283, I54 N. E. 105 (Ig26) ; Fox v. Mackreth, 2 Bro. C. C. 400,2 Cox Eq. Cas. 320 (Ch. I79I); Whichcote v. Lawrence, 3 Ves. 678 (Ch. I800); Wright v. Morgan, [I926] A. C. 788.

43. Pope v. Farnsworth, I46 Mass. 339, I6 N. E. 262 (I888). See Lewin, Trusts (13th ed. I928) 978, 979 . But see Stockhouse v. Barnston, 1o Ves. 466 (Ch. I805); Farrant v. Blanchford, I De G. J. \& S. IO7 (Ch. I863); Thomson v. Eastwood, 2 App. Cas. 215, 234, $237(1876)$. 
of consent, affirmation or release. It is to the acts of the beneficiary alone, not to the nature of the breach that the court looks, and the fact that there has been a most flagrant violation of the duty of loyalty by the trustee will not prevent the application of the doctrine, of estoppel. Of course, in situations where the acquiescence of the supposed cestui que trust was given before he assumed the relationship of beneficiary, it could be argued that the doctrine of loyalty could be safely ignored. Thus, in Chillingworth $v$. Chambers, ${ }^{44}$ the plaintiff and defendant as trustees made unauthorized investments. Later the plaintiff became by inheritance the beneficiary, and instituted action against the defendant. It was held that the plaintiff's acquiescence and concurrence, even though not in his character as beneficiary, was sufficient to estop him from recovering.

The most that can be said for the doctrine of estoppel is that it affords the court a converient terminology for reaching the desired result. Other legal principles have been pressed into service with little more applicability. Thus even the doctrine of volenti non fit injuria has been indicated as the proper ground for precluding relief to the beneficiary. In Fyler v. Fyler, ${ }^{4 \overline{5}}$ Lord Langdale in referring to a breach of trust, stated:

"It is said . . . yet it was done manifestly for the advantage of one of the cestui que trusts, and with the consent of some of the others; and if that were so-if all this has taken place with the consent of the parties now complaining, it certainly appears to me that they would not have any right to maintain this suit, for volenti non fit injuria. If they have authorized this course of dealing with their own fund, it would be in the highest degree unjust, to permit them to establish a claim against those who have acted under their authority." 46

When the beneficiary has actively instigated and assisted the trustee in the wrongful acts, then it may properly be considered that he has brought upon himself the loss complained of and has only himself to blame. But in cases where the wrong originates with the trustee and the beneficiary later assents, affirms or concurs, the theory of volenti non fit injuria is not applicable, since at the time of the wrong the beneficiary in no way assented to the risk.

\section{III}

In view of the extent to which trustees have been permitted to escape liability for every conceivable breach of trust, either under exoneration clauses in the trust instrument itself or by pleading the beneficiary's consent, acquiescence or release, the trust device as a means of affording a disposition of property becomes in many cases an abortive instrument. The class now in

44. [I896] I Ch. 685 .

45. 3 Beav. 550 (Ch. I84I).

46. $I d$. at 559,560 . 
need of protection is that of the settlors of trusts, among whom the belief is still fairly common that the right to control and dispose of their property after death is inherent and natural. It is of course recognized that such is not the case. ${ }^{47}$ Dispositions of property depend on and are now universally governed by statute, so that a testator or settlor seeking assurance as to what may legally be done with his property is confronted with legal regulations, universally embodying one, and in most of the United States two, restrictions: first, that one may not leave his property for a use which is against public policy $;^{48}$ secondly, the rule against perpetuities. ${ }^{49}$ But having created a trust in the light of these and other legal requirements, the settlor is presumably entitled to rely upon the fact that in the administration of his estate his expressed intent will be rigidly enforced and that neither courts, beneficiaries nor legislatures are competent to violate his instrument. In the application of the rule that the settlor's expressed intent is the guiding principle in the administration of a trust estate, deviation from the terms of a trust is zealously guarded against, even though such deviation may be claimed as beneficial and desirable. Only in cases of emergency, public policy, impossibility of performance, or where it is necessary to effectuate the very purpose of the trust itself, is deviation permitted or allowed, and then only upon proper application to the court.50

In a situation, therefore, where the settlor has set up a certain plan of distribution or attempted to preserve the corpus by authorizing investments only in certain types of approved securities, a request of the trustee to deviate, made in the honest belief that it would be beneficial, must necessarily be denied by the court, even though the prayer be joined in by both the beneficiary and the trustee. Despite this fact, where the trustee deviates with the consent, acquiescence or release of the cestui que trust, a sanction which the court itself could not grant is afforded the parties by the magic of these terms. There is no distinction to be discovered between trusts inter vivos and those created by will, as far as this inquiry is concerned. Under both situations, since the settlor or his personal representatives would, by the weight of authority, be unable to bring any action whatsoever to prevent such violation, ${ }^{51}$ there is offered unparalleled opportunity for trustees and beneficiaries,

47. Pollock \& Matrland, History of the English Law (2d ed. i899) 260-313, 348363 ; Minine, ANCIEnt Law (1oth ed. I906) 227-243. 632,658 .

48. See Scott, Control of Property by the Dead (1916) 65 U. of PA. L. Rev. 527, 542,

49. Gray, Rule Against Perpetuities (3d ed. I915) § 201,

50. See Scott, Deviations from the Terms of the Trust (I93I) 44 HARv. L. Rev. I205; Restatement, Trusts (Tent. Draft, I93I) $\$ \$ x 6 \mathrm{r}, \mathrm{I} 62$, I63.

51. See Restatement, Trusts (Tent. Draft, 1932) \$206. The heirs or personal representatives of the settlor cannot maintain such a suit. Field v. Andrada, I06 Cal. I07, 39 Pac. 323 (I895) ; Barrette v. Dooly, 21 Utah 81, 59 Pac. 718 (1899). A person who would incidentally benefit from the performance of a trust but who is not a beneficiary of the trust cannot maintain a suit against the trustee to enforce the trust. Town of Sharon v. Simons, $30 \mathrm{Vt} .458$ (1857); Shaw v. Lawless, 5 Cl. \& Fin. I29 (H. L. 1838) semble. But some cases have held that the settlor can maintain a suit against the trustee to enforce the trust or to en- 
innocently or collusively, to disregard completely the testator's directions as to payment of income, disposition of property, management of his business and countless other matters upon which he may have expressed himself.

In many cases the settlor seeking safety for the corpus expressly directs that investments are not to be made in other than those securities now or hereafter to be designated as legal investments. To apply the doctrine of estoppel in those situations so as to deny liability for breach of trust is to negative effectively not only the settlor's intent but the law of the particular jurisdiction involved. Statutory restrictions and the settlor's directions as to investment become, in the final analysis, nothing more than mere directions to be followed only in the absence of private arrangements between the trustees and beneficiaries. At least one court, however, has construed the legal investment statute of its particular state as imposing an obligation upon the trustee which not even acquiescence on the part of the cestui could relieve. In Aydelott v. Breeding, ${ }^{52}$ the Kentucky statute respecting legal investments by trustees made it unlawful to invest in bonds of railroads in operation for less than ten years or which had not paid interest on their obligations during a like period. The trustee invested in such bonds and when surcharge was requested for the loss occasioned thereby defended on the ground that the cestui had acquiesced. In dismissing his argument the court said :

"The contention of appellant that he made the investment in question at the instance of appellee is not sufficiently sustained by the evidence, and if it were, it may well be doubted whether a request upon her part to make the investment would relieve appellant from the responsibility of the loss incident thereto. Certainly her acquiescence in the investment would not have such an effect." 53

The position taken by the Kentucky court is, however, undoubtedly against the vast weight of authority, and a violation by a trustee of a statute defining legal investments is on the same footing as a violation of a duty defined by the trust instrument, so far as the ability of the beneficiary to "estop" himself is concerned. ${ }^{54}$

In addition to the fact that the settlor's intention as to the distribution of his property is deprived of an effective sanction, the interests of the

join or obtain redress for a breach of trust. Carr v. Carr, I85 Iowa 1205, I7I N. W. 785 (I9I9) (trustee conveyed land to beneficiary; suit maintainable, but conveyance proper); Abbott v. Gregory, 39 Mich. 68 (1878).

52. III Ky. 847, 64 S. W. 916 (I90I).

53. Id. at 856,64 S. W. at 918 . In Illinois, the statute provides that no trustees shall invest trust funds in any bonds in which "cautious and intelligent persons do not invest their own money". ILL. REv. STAT. (Cahill, I92I) § I44, c. 3. Under such a provision as this, would not the court necessarily have to require a higher degree of competency before permitting the cestıi que trust to be estopped by his approval of the investment? Certainly some proof that the cestui was a cautious and intelligent person should be required in all cases, and especially where the testator by limiting the beneficiary's power to deal with the property has signified that he does not consider the beneficiary sufficiently able to be trusted with its administration.

54. See Restatement, Trusts (Tent. Draft, I932) §§ 208-210. 
beneficiary are seriously affected by the doctrine of exceptions. In many instances, the deliberate purpose of the settlor in creating the trust is to remove from one whom he deems incapable of managing his own affairs the power to deal at will with the trust property. The inabilities or inexperience of such a one may afford the greatest practical justification for the settlor's lack of confidence, and yet may easily not be such as to destroy the legal requisite of competence. To permit such a beneficiary to consent or cooperate effectively in perpetrating a departure from the express terms or ordinarily legal effects of the trust is prejudicing one who is entitled to have his affairs regulated by better minds than his own.

The views which some of the early English Chancellors expressed as to the application of the exceptions to married women's separate use trusts without power of anticipation were never later confirmed, but, as has been shown, the application of the exceptions was left largely to the discretion of the court. In spendthrift trusts, designed to protect the cestui que trust from his own follies and inexperience, it would be expected that the courts would refuse to apply the doctrine of estoppel; yet even beneficiaries under spendthrift trusts have been estopped by their consent, acquiescence or release. ${ }^{55}$

Further, the doctrine of the exceptions permits an unwarranted delegation to beneficiaries of the duty of management. Many trustees, by the practice of consultation, which is prevalent, are permitted to place beneficiaries in the compromising position of being required either to approve or disapprove of the contemplated investment. While mere knowledge of a contemplated breach of trust has been held not to amount to acquiescence, yet in estopping the beneficiaries there is no clear line of demarcation observed, and courts have sometimes placed great weight on the fact that the beneficiaries were consulted, kept advised and never dissented. ${ }^{56}$ Especially where trust companies describing themselves as experts are employed for the very purpose of relieving settlors and beneficiary of the details of management are such actions unwarranted. Having been selected because of their purported reliability and competence, they should not be permitted to divide responsibility, and no action of the beneficiary regarding management should relieve them from the burdens of their trust.

55. Sherman v. Parrish, 53 N. Y. 483 (1873); Woodbridge v. Bockes, 59 App. Div. 503, 69 N. Y. Supp. 4I7 (4th Dep't I90I), aff'd I70 N. Y. 596, 63 N. E. 362 (1902). But cf. Rehr v. Fidelity-Philadelphia Trust Co., 310 Pa. 30r, I65 Atl. 380 (I933) (beneficiary under spendthrift trust may not agree to termination or deviation even though there are no remainders over); Stanbaugh Estate, I35 Pa. 585, 19 Atl. 1058 (1890). The writer has not attempted to exhaust or classify the cases upon spendthrift trusts as the views in each particular jurisdiction vary not only in their reaction to the applicability of the doctrine of estoppel in such situations, but also as to the nature and definition of what constitutes spendthrift trusts.

56. See Armitage Estate, I95 Pa. 583, 46 At1. II7 (1900), in which the court held that as the cestuis had been consulted with regard to the action of the trustee in making investments, they were estopped from surcharging for losses occasioned in connection therewith. 
The situation has been admirably summed up in the dissenting opinion in Estate of Allis. ${ }^{57}$ In that case, investments had been made in certain speculative securities for which surcharge was requested. In addition to the fact that the corporate trustees had acted under an exoneration clause permitting investment in non-legal securities, the court further found that the beneficiaries by concurring and acquiescing should be estopped. Crownhardt, $\mathrm{J}$. stated in his dissent:

". . . there can be no estoppel.. . . To do so is to disregard the terms of the trust and to hold the cestui que trust responsible for the obligations imposed on the trustee. That disregards the very purpose of the trust. In creating the trust the testator deemed the widow and orphan incompetent to manage the estate. He therefore placed his faith in the trustees he named and in the supervisory power of the courts. He placed his estate beyond the power of his widow or his daughter to dissipate through their inexperience or improvidence. By applying the rule of estoppel, the court circumvents the terms of the trust and the will of the testator. The will did not permit the beneficiaries to squander the estate, and the court should not permit the trustees to do so under cover of consent of the beneficiaries." 58

Whether the testator or settlor could under the present state of the law effectively protect his beneficiary from his own follies or prevent collusion between the cestui and the trustee is a question open to serious doubt. Suppose a testator, having been fully advised as to the present extent of the exceptions to liability, directs the preparation of a trust instrument containing the following clause:

"Having been fully advised that my trustee may safely depart from the terms of this trust where requested, or where the consent, release or affirmation of my beneficiary has been obtained, it is my express wish and direction that my trustee shall under no circumstances depart from the terms of this trust without leave of court first had and obtained; further that my beneficiary shall be without power of consent, affirmation or release in and to any violation by the trustee under the terms of this trust, should the same occur or be proposed."

With such clear admonition from the testator the doctrine of estoppel would seem to vanish into thin air. Certainly, the express wish of the testator should materially affect the possibility of inducement as an element of estoppel, upon which the trustee could rely. The inequity of unfairness could not be pleaded. It is true, however, that the court would then be faced with a situation wherein the beneficiary, otherwise sui juris, would be rendered incapable of entering into a contract of release during the life of the trust. It is submitted that such restraint on the freedom of contract is not too

57. I9r Wis. $23,37,209$ N. W. 945,950 (I926).

58. $I d$. at 59 , I9I Wis. at 958 . 
alarming as an innovation of the law and should not be considered as a serious deterrent in deciding in favor of the validity of such a clause. In many respects the relationship between the trustee and the beneficiary raises duties imposing limitations upon the freedom of contract. The matter necessarily resolves itself into balancing the effect of a testator's or settlor's instrument against that of a consensual arrangement between the beneficiary and the trustee. Since the right of the beneficiary to share in the testator's bounty is based on the settlor's instrument itself, his freedom of contract in relationship to the trust might well be considered a derivative right rising no higher than that which the instrument expressly or impliedly confers. By accepting the benefits of the trust, it could be said that the beneficiary manifests an election to be found by its terms.

But lying beyond any technical possibilities of rationalizing a change in the present law is the question of the modern wisdom of a doctrine which developed and flourished under social and economic conditions long since departed. 